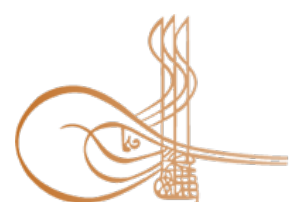

www.turkishstudies.net/history
Turkish Studies - Historical Analysis

eISSN: 2667-5552

Research Article / Araștırma Makalesi

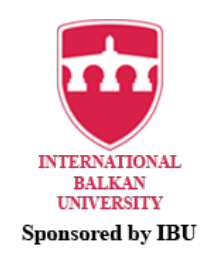

Sponsored by IBU

\title{
İngiltere ve Amerika'nın 2. Dünya Savaşı Yıllarında Türkiye'deki Azınlık Politikası
}

\author{
British And American Minority Policies in Turkey During World War II
}

\author{
Hakan Güngör*
}

\begin{abstract}
Turkey stayed neutral until the last months of World War II, but it lived the economic crisis caused by the war in all its dimensions. Because of the possibility of being attacked by the Allies or the Axis states, Turkey perused a war economy and recruited a million men in the army. Some of the capital owners in Turkey, who took advantage of this war, engaged in black-marketing and stocking. Since all these developments caused inflation and the economy to deteriorate, the Saraçoğlu Government had to take some measures. One of these measures applied by the government was the Wealth Tax Law (Varlık Vergisi Kanunu). Although the law stipulates equal taxation of all citizens based on their wealth, Non-Muslim minorities were subjected to very high taxation compared to the Muslim Turks. Because monirities held most of the capital in Turkey, Wealth Tax effected them the most. Although all citizens had equal rights and freedoms in Turkey, the implementation of the Capital Tax began to be seen as Turkification of the economy and even racism. Minorities, especially Jews, frequently applied to Britain and the United States to correct the unfair tax distribution. However, the United States and Great Britain believed that a non-belligerent Turkey would contribute their eventual victory, and they did not want to deteriorate their relations with Turkey. This article examines the British and the American policy towards non-Muslim minorities in Turkey during the war years in the light of the British and the US consulate archival documents. Thus, this study investigates to what extent the foreign states intervened in the internal affairs of Turkey during WWII.
\end{abstract}

Structured Abstract: Following the foundation of the republic, Turkey pursued a policy of Turkification in all areas including the economy. This was a very common practice for the nation states. Although many nation states, which was founded after the First World War, installed racism and hostile attitudes towards their minorities, Turkey granted equal rights and freedoms to all citizens without distinction of race and religion. However, she wanted the Turkish people, who fought in the forefront during the War of Independence, to become stronger economically. Because of the possibility of being attacked by the Allies or the Axis states during WWII, Turkey perused a war economy and recruited a million men in army. At the same time, some of the capital owners in Turkey, who took advantage of this war, engaged in black-marketing and stocking.

Since all these developments caused inflation and the economy to deteriorate, the Saraçoğlu Government had to take some measures. In order to alleviate the economic burden of World War II and to strengthen the country's defense, the Turkish Government had to implement some extraordinary taxation methods. Thus, the government passed the Wealth Taxation Law or the Capital Law. Although this tax law does not include discrimination and inequality, it is understood that some local governments use this to

\footnotetext{
${ }^{*}$ Arş. Gör. Dr., Ordu Üniversitesi, Fen Edebiyat Fakültesi, Tarih Bölümü Res. Asst. Dr., Ordu University, Faculty Science of Letters, Department of Histyory ORCID 0000-0002-8282-5481 hakangungor490@gmail.com

Cite as/ Atıf: Güngör, H. (2020). İngiltere ve Amerika'nın 2. Dünya Savaş1 yıllarında Türkiye'deki azınlık politikası. Turkish Studies - History, 15(2), 499-513. https://dx.doi.org/10.29228/TurkishStudies.43264

Received/Geliş: 30 April/Nisan 2020

Accepted/Kabul: 20 June/Haziran 2020

Copyright $($ INTAC LTD, Turkey
} 
marginalize non-Muslims and to break their economic power. Even though all citizens had equal rights and freedoms in Turkey, the implementation of the Capital Tax began to be seen as Turkification of the economy and even racism.

Minorities, especially Jews, frequently applied to Britain and the United States to correct the unfair tax distribution. Turkish minority communities frequently asked for help from Britain and the USA to get rid of heavy tax burdens, but they did not receive a formal positive response until 1944. The priority of these two states was the defeat of Germany. They did not want to risk their relations with the neutral Turkey by intervening in her internal affairs. Because such action could have pushed Turkey towards the Germans. As it is clear from the British and American archival documents that they did not want their representatives in Turkey to get involve in the Turkish minorities' question. This article examines the British and the US policy towards non-Muslim minorities in Turkey during the war years in the light of the British and the US consulate archival documents. Thus, this study investigates to what extent the foreign states intervened in the internal affairs of Turkey during WWII.

A series of articles and books have been written about the Wealth Tax. Many of these studies have contributed to the literature by dealing with different aspects of the tax. The part that was not examined and remained in the dark was the behavior and attitude of foreign states towards this tax. In this sense, the aim of the research is to contribute to the development of different perspectives by adding some nuances to the discussions on the existing Wealth Tax Law. During the research we found that non-Muslim minorities applied to the United States and United Kingdom for the cancellation or easing the tax. In this sense, we looked for ambassador Steinhardt's Papers in Library of Congress, archival documents in Franklin D. Roosevelt Library and in the National Archives. We also researched for the British archival documents and these documents were conformed with the Turkish archival documents. In order to complete this research, we went through hundreds of documents. The hardest part of doing this research was to locate archival documents in all these three countries and receiving them. This research's ultimate goal is to contribute to the field.

Keywords: Minorities, Jews, United Kingdom, United States, the Wealth Tax Law

Öz: Türkiye İkinci Dünya Savaşı'na fiili olarak girmemesine rağmen, savaşın neden olduğu ekonomik buhranı bütün boyutlarıyla yaşamıştır. Türkiye, Müttefik veya Mihver devletleri tarafından saldırıya uğrama ihtimalinden dolayı savaş ekonomisine geçmiş ve bir milyona yakın askeri silah altına almıştır. Bu savaş ortamını fırsat bilen bazı sermaye sahipleri karaborsacılık ve stokçuluk yapmıştır. Bütün bu gelişmeler enflasyonun yükselmesine ve ekonominin bozulmasına neden olduğundan Saraçoğlu Hükümeti bazı tedbirler almak zorunda kalmıştır. Hükümetin başvurduğu bu tedbirlerden birisi Varlık Vergisi Kanunu'ydu. Kanun, bütün vatandaşların mal varlıklarına göre eşit vergilendirmeyi öngörmesine rağmen, uygulamda Türkiye'deki gayrimüslim azınlık toplumu Müslüman Türklere göre yüksek vergilendirmelere tabi tutuldular. Türkiye'deki sermayenin büyük bir kısmı azınlıkların elinde olmasından dolayı Varlık Vergisi'nden en çok onların etkilenmesi doğaldı. Fakat bütün vatandaşların eşit hak ve hürriyete sahip olduğu Türkiye'de bu durum İktisadi Türkleştirme ve ırkçılık olarak görülmeye başlandı. Başta Yahudiler olmak üzere Türkiye'deki azınlıklar adaletsiz vergi dağılımının düzeltilmesi için sık sık İngiltere ve ABD'ye müracaat ettiler. Ancak tarafsız bir politika yürüten Türkiye'nin nihai zaferlerine katkı sağlayacağını düşünen bu devletler, Türkiye'yle olan münasebetlerini savaş esnasında bozmak istemediklerinden Varlık Vergisi'ne belli bir süre kayıtsız kaldılar. Bu makale, İngiltere ve ABD'nin savaş yıllarında Türkiye'deki gayrimüslim azınlıklara yönelik politikasını konsolosluk arşiv belgeleri ışı̆̆ında incelemektedir. Böylece, yabancı devletlerin İkinci Dünya Savaşı'nda Türkiye'nin iç meselesine ne denli müdahale ettiği araştırılmıştır.

Anahtar Kelimeler: Azınlıklar, Yahudiler, İngiltere, ABD, Varlık Vergisi

\section{Giriş}

Cumhuriyet'in kuruluşundan sonra Türkiye'de birçok alanda Türkleştirme politikası uygulandı. $\mathrm{Bu}$ politikanın başlıca uygulandığı alanlar eğitim, kültür ve iktisadi hayat oldu. Cumhuriyet, Türkleştirme politikasıyla Ziya Gökalp'ın 'Vatan' şiirinde ifade ettiği gibi Türk kimliğinin egemenliğini her alanda ortaya koydu. Vatanın işgali döneminde yabancılar tarafindan 
itibarsızlaştırılan Türk etnik kimliğinin tekrar değerine kavuşması hedeflendi. Kurtuluş Savaşı'ndan galip çıkan Türkiye'deki bir kısım insanlar, gayrimüslimleri 'öteki' ve işgalcilerin 'işbirlikçisi' olarak görmeye başladı. Bu nedenle azınlıkların elindeki ticareti ve sanayiyi azaltarak, kapitali Müslüman Türk sınıfının eline geçirmeyi hedefledi. Devlet milli burjuvazi bir sınıf oluşturarak, yabancı ve azınlık cemaatin eline geçmiş olan sermayeyi Türk halkının kontrolüne geçirmek ve iktisadi bağımsızlığa kavuşmak istiyordu (Bali, 2010, 232-233). Örneğin İş Bankası 1924'te kurulduğunda, Türk toplumunun bankacılık alanında deneyim sahibi olmamasından azınlıklardan yardım ve destek alınması önerilmişti. Bu öneriye birçok kişi karşı çıkmış, İş Bankası'nın "milli bankacılığımızın modern bir okulu" olmasını istemişlerdi. ${ }^{1}$ Cumhuriyet döneminin ilk yıllarında bazı delegeler iktisadi Türkleştirme politikasını dile getirerek gayrimüslim cemaati hedef haline getirdi. $\mathrm{Bu}$ delegelerden biri olan Salihli delegesi Zahit Bey bir konuşmasında, "Bu Yahudiler, biz İzmir'de ticaret ederken bizi soydular. Yunanlara casusluk ettiler... Bu Yahudiler bugün Türk gençliğinin iktisâb etmek istediği iktisâdi vaziyete tamamıyla hâkim olmuştur" (Üstel, 1997, 200) diyerek iktisat alanındaki millileşmenin kendisine göre önemine değinmiş̧tir. Zahit Bey ve onun gibi birçok kişi, Yahudi cemaatinin ve diğer azınlıkların iktisadi hayattaki etkinliğinin kırılmasını istiyordu. Türkiye'deki iktisadın millîleştirilmesine dair bir nutukta Adliye vekili Mahmut Esat Bey'den (Bozkurt) geldi. Mahmut Esat Bey, Ödemiş’teki konuşmasında adeta Türkiye'deki birçok kişinin hislerine tercüman oldu:

Düne kadar vapurlarda, şimendiferlerde memleketimizin bütün ticari ve mali müesseselerinde kimler çalışıyordu ve bunlar kimlerin elinde bulunuyordu? Türk olmayanların değil mi? Bugün kimin ellerindedir? Türklerin! Bütün bunlar CHF’nin siyasetinin mahsuludur. Bağlar, bahçeler, hatta dağlar, ovalar, mal mülk memleketin iktisadiyatı Türk olmayanların elinde değil miydi? Bugün bütün bunlar Türklerin eline geçti. Bu da CHF'nin siyasetinin semeresidir. Düne kadar yabancıların yanında amelelik yapan binlerce Türkün bağ, bahçe, mülk sahibi olduğunu görüyoruz....Benim fikrim, kanaatim şudur ki, dost da düşman da dilesin ki bu memleketin efendisi Türk’tür. Öz Türk olmayanların Türk vatanında bir hakkı vardır, o da hizmetçi olmaktır, köle olmaktır (Hakimiyeti Milliye, 19 Eylül 1930).

Cumhuriyet erken döneminde sarf edilen ve uygulanan bu politikalar, Avrupa veya Amerika Birleşik Devletleri'ndeki ırkçı politikalarla karıştırılmamalıdır. Nitekim Cumhuriyetimizin kurucuları ilk günden beri ayrıcalıklı ve imtiyazlı bir toplum oluşturmak istemedikleri, eşit ve sınıfsız bir toplum teşekkül etme gayretin de oldukları için herkese eşit muameleyi gerektiren yasalar benimsenmiş, din ve rrk üstünlügünü ön gören yasalarsa reddedilmiştir. Cumhuriyet dönemindeki Türkleştirme çalışmaları 1rkçılık değil, Anadolu ve İstanbul işgaliyle birlikte Türklerin elinde alınan ve azınlıklara verilen sermayenin yeniden asıl sahibine verilmesiydi. Bu iktisadi Türkleştirme politikası 2. Dünya Savaşı yıllarında da devam etmesine rağmen, ülkemiz Nazi zulmünden kaçan binlerce Yahudi mülteciye kucak açmış ve ev sahipliği yapmıştır.

II. Dünya Savaşı'nın 1939'da başlamasıyla Türkiye olağanüstü önlemler alarak savaşa hazırlanmaya çalıştı. Ülke sınırlarının korunması ve muhtemel bir savaşa girme ihtimaline karşı bir milyon asker silah altına alındı. Milli savunmaya yönelik tedbirler masrafların hızlıca artmasına neden oldu. Hükümet fazla para basarak bunun önüne geçmeye çalıştıysa da 1942 yılının ilk aylarından itibaren yüksek kazançlı şirket ve kişileri vergilendirme yolunu aramaya girdi. Başbakan Refik Saydam 7 Temmuz 1942 günü ölünce, yerine Dışişleri Bakanı Şükrü Saraçoğlu başbakan olarak atandı ve yeni bir hükümet kurdu. Başbakan Refik Saydam'ın ölümünden yaklaşık 15 gün önce Almanya'nın sınır komşusu olduğumuz Rusya'ya saldırması ve Balkanlarda tam hakimiyet kurması ülkemizin güvenliği için ciddi bir tehdit oluşturmaya başladı. Ancak Başbakan

\footnotetext{
${ }^{1}$ Osmanlı Bankası'nın milli olmamasını en çok eleştirenlerden biri de Mahmut East Bozkurt'tur, onun bu husustaki detaylı görüşü için bkz., Mahmut Esat Bozkurt, Ulus Gazetesi, 22 Ağustos 1938; M. Akif Tural, Atatürk Devrinde Ikktisadi yapılaşma ve Celal Bayar (1920-1938), (Ankara: Kültür ve Turizm Bakanlığı Yayınları, 1987), s.97-98.
} 
Saraçoğlu'nun yüz yüze kaldığı en büyük zorluk yakın olan Alman tehdidi değil, savaş zamanı seferberlik önlemlerinden kaynaklanan enflasyon ve ekonomik sorunlard. Türkiye her ne kadar tarafsız bir politika sürdürdüyse de savaşın getirdiği ekonomik buhranla baş etmekte zorlanıyordu. Ulusal ekonominin temelinin sarsıldığı bu dönemde artan stokçuluk, karaborsacılık, komisyonculuk ve fiyat artışının faturası genelde azınlık cemaatlere kesiliyordu. Başbakan Saraçoğlu 5 Ağustos 1942 günü TBMM'de yaptığı konuşmada Türkleștirme politikasının ehemmiyetine değinerek, "Arkadaşlar biz Türküz, Türkçüyüz ve daima Türkçü kalacağız. Bizim için Türkçülük bir kan meselesi olduğu kadar ve lâakal [en az] o kadar da bir vicdan ve kültür meselesidir.... Biz ne sarayın, ne sermayenin ne de sınıfların saltanatını istiyoruz. İstediğimiz sadece Türk milletinin hakimiyetidir" (Ayın Tarihi, Ağustos 1942) Ülke ekonomisinin kötü gidişatı ve basının bu kötü gidişatın müsebbibi olarak Yahudi Türklerini göstermesi sonunda hükümeti harekete geçirdi. ${ }^{2}$

Saraçoğlu Hükümeti, 11 Kasım 1942'de Varlık Vergisi Kanunu'nu uygulamaya koydu (Resmi Gazete, 11 Aralık 1942). Bu yasa hükümete olağandışı zamanlarında büyük kâr elde eden şahıs ve şirketlerin servetlerini ve mallarını vergilendirme imkânı veriyordu. Dolayısıyla Ankara yönetimi, II. Dünya Savaş'ının ekonomik yükünden dolayı devletin servete uyguladığı bir vergi olduğunu iddia ediyordu. Başbakan Saraçoğlu bu verginin gerekçesini şöyle açıklıyordu:

$\mathrm{Bu}$ kanun ile takip ettiğimiz hedef tedavüldeki paraları azaltmak ve memleket ihtiyaçlarımıza karşılık hazırlamaktır. Bu böyle olmakla beraber bu kanun tatbikinden, Türk parasının kıymetlenmesi, muhtekirler üzerinde toplanan halk buğuzunun silinmesi, vergileri ödemek için bizzarure [ister istemez] satışa çıkarılacak malların fiyatlarında bir itidal husule getirilmesi gibi tâli [ikincil] faydaların tahassül etmesi [ortaya çıkması] de imkân haricinde addedilemez (Ayın Tarihi, Kasım 1942).

Başbakan Saraçoğlu TBMM'deki konuşmasında yukarıdakileri ifade etmesine rağmen, iki gün önce basına kapalı yapılan CHP grup toplantısında Varlık Vergisi'nin iktisadi Türkleştirme politikası olduğunu illeri sürüyordu. Saraçoğlu basına kapalı olan toplantıda Varlık Vergisi Kanunu anlatırken "Piyasamıza egemen olan yabancıları böylece ortadan kaldırarak, Türk piyasasını Türklerin eline vereceğiz" diyordu (Barutçu, 1977, 263). Bu dönemlerde İstanbul Maliye Bakanlığı'nda Defterdar olarak çalışan Faik Ökte'de kaleme aldığı The Tragedy of Turkish Capital Tax adlı eserinde bu kanun sıkıntılarına işaret ediyordu.

II. Dünya Savaşı sırasında Defterdar olarak çalışan Faik Ökte'ye göre Varlık Vergisi ekonomik sıkıntıya çözüm değildi; ekonomik yükü azaltmanın ve enflasyonu düşürmenin en iyi yolu belki de piyasaya sürülen aşırı para birimini çekmekti (Ökte, 1987, 15). Ayrıca Hükümet, Varlık Vergisi'nin gerekçesini ekonomiyi ayakta tutmak, savunma harcamalarını karşılamak, karaborsacılık ve stokçulukla mücadele etmek olarak göstermesine rağmen, vergi esas olarak gayrimüslim cemaate, özellikle de Yahudilere ve Hristiyanlara uygulandı. Kanun, bu vergi 'gayrimüslimlerden alınır' hükmüne yer vermemesine rağmen, verginin uygulanış biçimi incelendiğinde bu verginin özellikle Yahudi cemaatini hedef aldığını ve onları ekonomik olarak zayıflatmayı hedeflediğini göstermektedir.

Saraçoğlu hükümeti Varlık Vergisi’yle ekonomideki azınlık egemenliğine son vererek, sermayeyi Türklerin eline geçirmeyi amaçlyyordu. Zaten dönemin sermaye ve gayrimenkul hareketliliği gözlemlendiğinde, "Varlık Vergisi sayesinde, gayrimüslim azınlıklardan nüfusun diğer kesimine doğru bir servet transferinin yapıldığını görmemek mümkün değildi” (Aktar, 2004, 10). Türkiye'deki sermayenin büyük bir kısmını elinde bulunduran Yahudiler bu vergiden en çok etkilenen cemaat oldu. Başbakan Saraçoğlu basına hitaben yaptığı konuşmada, Varlık Vergisi Kanunu'nun bu ülkenin misafirperverliğinden yararlanan ve zengin olan, ancak zor zamanlarda ülkeye yardım etmekten kaçınanlara ciddi biçimde uygulanacağını belirtti (Cumhuriyet Gazetesi, 21

\footnotetext{
${ }^{2}$ Yahudileri karalayan bir dizi haber 1942 yazında gazetelerde çıktı, bkz., "iki Yahudi çocuğu hava kurumu için toplanan rozet paralarını çaldılar” Cumhuriyet, 31 Ağustos 1942; "İstif̧̧i iki Yahudi yakalandı” Tasvir-i Efkâr, 9 Eylül 1942.
} 
Ocak 1943). Görünüşe göre Saraçoğlu esas olarak Yahudi cemaatini, özellikle on yedinci yüzyılda İslam'a dönüştürülen Dönme Yahudilerini hedef almıştı. ${ }^{3}$ Ancak hükümet, Türkiye'yi dış dünyaya faşist bir devlet olarak göstermemek, İngiltere ve ABD'nin tepkisini çekmemek için bu vergilendirmenin bir Türkleştirme politikası olmadığına, aksine savaş ekonomisinin zorunluluğundan ortaya çıkmış bir kanun olduğunu ifade ediyordu. Bu tür açıklamalara rağmen, hükümetin azınlıkları sindirmeye ve ötekileştirmeye çalıştığını yabancı devlet bürokratları yazışmalarında ifade etmekteydiler.

ABD Türkiye Büyükelçisi Laurence Steinhardt ABD Dışişleri Bakanı'na verdiği raporda, Varlık Vergisinin Müslüman olmayan Türk azınlıklara yönelik olduğunu açıkça belirtiyordu. Bu raporda aynı şirkette çalışan yabancıların ve Müslüman Türklerin maaşlarının farklı vergilendirildiği ve Müslüman olmayanların maaşları büyük oranda vergi olarak kesildiğini yazıyordu (Steinhardt, 19 Aralık 1942). Bununla birlikte Varlık Vergisi yabancı yatırımcılar içinde ciddi bir kaygıya sebep oldu. ABD Stratejik Hizmet, Araştırma ve Analiz Şube Müdürlügü̈'nün ABD Dışişleri Bakanlığına gönderdiği bir raporunda, "Türk Hükümetinin Osmanlı Devleti'nin keyfi yöntemlerine geri dönmesinden çekindiklerini" yazarak bu kaygıyı açıkça ortaya koymaktaydılar (Office of Strategic Service, 3 Mayıs 1944). Nitekim Varlık Vergisi’nin uygulanış biçimi Cumhuriyetimizin laiklik prensibine uymuyor, din ve ırka göre insanları sinıflandırıyordu.

Varlık Vergisi Kanunu TBMM'den geçip yasallaşınca, Maliye Bakanlığı bir müfettiş heyeti oluşturdu. Faik Ökte, Mehmet İzmen ve Hesap Uzmanı Rasim Saydar'ın da yer aldığı bu heyet, vergi mükelleflerinin ödemek zorunda kalacağı miktarı belirlemek için çalışmalara başladı. Ancak Faik Ökte'nin aktardığına göre heyet işe başlar başlamaz toplumu sınıflandırmayı önerdi. Bu sinıflandırma önerisi ilk olarak heyet üyesi olan Mehmet İzmen'den geldi. Böylece vergi mükellefleri dini aidiyetliklerine göre listelendi. Bu liste başlangıçta Müslümanlar için M ve Gayrimüslimler için G olarak sınıflandırma yapmış olmasına rağmen, Ecnebi için E ve Dönmeler için D 'de kısa bir süre içinde listeye eklendi (Ökte, 19; Lewis, 298). Bu sınıflandırma herkesi eşit gören Türk medeni kanununa ve devletin laiklik ilkesine aykırıydı. Fakat buna rağmen vergi mükellefinin değerlendirmesini belirleyen yıllık gelir kaynağı göz ardı edilerek, dini mensubiyet referans olarak alınması Cumhuriyetin en temel değerleriyle çelişiyordu. Ancak bu duruma rağmen, verginin uygulanışından herhangi bir taviz verilmedi.

Maliye Bakanlığının yetkilendirdiği heyet, mükellefler için belirlediği miktar kesindi, itiraz için mahkemeye bile gidilemezdi. Mükellefler belirlenen tutarı 15 gün içinde ödememesi durumunda varlıklarına el konulacaktı. Mal varlıkları belirlenen vergiyi karşılamayanlar ise Aşkale'deki çalışma kampına gönderecekti (Resmî Gazete, 11 Aralık 1942). Aşkale'ye çalışmak için kampa gönderilen 2.057 kişinin 1.400 'ünü gayrimüslimler oluşturmaktaydı. Çalışmaya mahkûm edilmiş olanların yarısından fazlasının azınlıklardan oluşması, verginin adaletsiz uygulandığının bir işaretiydi (Akar, 2009, 107). Vergi tahsili esnasında gayrimüslimlerle ortaklığı olan Türk şirketler, siyasi güçlerini kullanarak vergilerin bir kısmını ödemediler. Vehbi Koç bunlardan bir tanesiydi ve vergilendirme usulüne itiraz ederek, "Müslüman (M) grubu ve ortakları, şeklinde yeni oranlar hazırlayarak, başbakana başvurdu. Daha sonra tahsilat işlemi Koç’un hazırladığı oranlar doğrultusunda yürütüldü. Böylece Vehbi Koç'un 1 milyon TL olan vergisi 600000 TL'ye indirildi.” Bunun yanı sıra, 378 Müslüman vergi mükellefi üzerinde yapılan çalışma da 6.832.372 TL olan vergilerinin tecil edildiği anlaşılmıştır (Akar, 2009, 88). Bu tür uygulamalar yabancı diplomatlar tarafından da yakından takip edilmekteydi. ABD Büyükelçisi Steinhardt bu durumu raporunda, "Türk Hükümet yetkilileri birçok adaletsizliklerin yaşandığını bilmelerine rağmen, kamusal konuşmalarda sürekli olarak Varlık Vergisi’nin gayrimüslimlere karşı olduğunu reddediyorlar”' demekteydi (Steinhardt, 18 Ocak 1943).

\footnotetext{
${ }^{3}$ Osmanlı Devleti'nden Türkiye Cumhuriyeti'ne Dönmeler hakkında ayrıntılı bir bilgi için bkz., Marc David Baer, The Dönme: Jewish Converts, Muslim Revolutionaries, and Secular Turks, (Stanford, Calif: Stanford University Press, 2010); Selim Deringil, Conversion and Apostasy in the late Ottoman Empire, (Cambridge: Cambridge University Press, 2012).
} 
Türkiye, Varlık Vergisini Mart 1944'te Resmî Gazete 'de yaptığı ilan ile iptal ettiğini duyurdu (Resmî Gazete, 17 Mart 1944). Verginin kendisi yasal olsa da, uygulanması adaletsizlik yarattı ve yabancıların Türkiye'ye olan güvenini sarstı. Bununla birlikte, hükümet vergilendirme ile birkaç şeyi başardı: büyük miktarda nakdin hızlı bir şekilde kazanılması, kârlılık, enflasyonun azaltılması, azınlıkların ekonomik durumunun zayıflaması ve devletin ithalat-ihracat ticareti üzerindeki kontrolünün kurulması bunlardan sadece birkaç tanesiydi (Wright, 2 Şubat 1943).

Varlık Vergisi hakkında bir dizi makale ve kitap yazılmıştır. Bu araştırmaların birçoğu Varlık Vergisini ve uygulanışını farklı yönlerle ele alarak literatüre katkı sağlamıştır. Bu verginin incelenmeyen ve karanlıkta kalan kısmı yabancı devletlerin bu vergiye karşı davranış ve tutumlarıydı. Bu anlamda, araştırmanın amacı mevcut Varlık Vergisi Kanunu üzerindeki tartışmalara bazı nüanslar ekleyerek farklı bakış açılarının gelişmesine katkı sağlamaktır. Yapılan incelmeler neticesinde, Türkiye'deki gayrimüslimler savaş boyunca Varlık Vergisi'nin iptali veya hafifletilmesi için başvurdukları iki devlet tespit edildi, bu devletler ABD ve İngiltere'ydi. Bu anlamda ABD Türkiye Büyükelçisi Steinhardt'ın raporları, ABD konsolosluk raporları ve ABD Başkanı Franklin D. Roosevelt'in arşivinde bulunan belgeler ve ABD Milli Arşivi'ndeki belgeler detaylı bir şekilde incelendi. İngiltere'nin Varlık Vergisi'yle ilgili belgeleri İngiliz Milli Arşivi'nde bulunmaktadır. Bu belgeler orijinal haliyle Rıfat N. Bali tarafindan "The Wealth Tax (Varlık Vergisi) Affair Documents from the British National Archives" adı altında yayınladı. ABD arşiv belgeleri ve İngiliz arşiv belgelerinin Türkiye'deki arşiv belgeleri, gazeteler ve hatıratlarla teyit edilmesi gerekmekteydi. Çok yönlü bir araştırmanın ürünü olan bu makale, ABD ve İngiltere'nin Türkiye'deki azınlıklara karşı politikalarını incelmektedir.

\section{İngiltere'nin Varlık Vergisi'ne Tepkisi}

Türkiye Büyük Millet Meclisi'nin 11 Kasım 1942'de kabul ettiği Varlık Vergisi Kanunu, stokçuluk ve karaborsacılık üzerinden yüksek kar elde etmeye çalışan kişi ve şirketleri vergilendirmeyi amaçladı. Yasa, kişi ve şirketler arasında ayrımcılığı gözetmemesine rağmen, uygulamada ayrımcı ve keyfiydi. Müslüman olmayan tüccar ve sanayiciler ağır vergilendirilirken, benzer sermaye ve zenginliğe sahip Müslüman Türk vatandaşlarına çok daha az vergilendirme yapıldı. Yasa ayrıca belirlenen vergiyi ödemeyenler için zorunlu çalışmayı öngörüyordu. Borcunu ödeyemeyen vergi mükellefleri, yol yapımı için sıcaklığın -25 ve -35 derecelere kadar düştüğü Erzurum'daki Aşkale'ye gönderildi. Buraya çalışmaya gönderilenlerin tamamına yakını gayrimüslimlerden oluşuyordu. Gayrimüslimler maddi ve manevi olarak son derece ağır bir darbe aldı. Vergilerini ödemek için varlıklarını Müslüman Türk vatandaşlarına yok pahasına satarak bir gecede yoksul oldular. Türkiye Cumhuriyet'inin laiklik ve eşitlik prensipleri üzerinde kurulmasından dolayı kendilerini güvende gören gayrimüslim Türk cemaatleri, Varlık Vergisi Kanunu'yla tüm umutlarını yitirdiler. Din ve 1rk farkı gözetmeksizin herkese eşit muameleyi ön gören Anayasa'ya karşı olan inançları derinden sarsıldı.

Varlık Vergisi Kanunu uygulanmaya konduktan yaklaşık bir ay sonra İngiltere'nin Ankara Büyükelçiliği, bu vergi yükünün büyük bir kısmının azınlıklara yüklenildiğini İ̉ngiltere Dışişleri Bakanlığı'na bildirdi. Yahudi ve Ermenilere karşı özellikle ayrımcılığın söz konusu olduğu ifade ediliyordu. ${ }^{4}$ İngiliz Başkonsolosluk raporlarında bu verginin savunmasız azınlıkları hedef aldığını, vergisini veremeyenlerin çalışma kamplarına gönderildiği ifade edilmekteydi. İngiliz Dışişleri Bakanlığına gönderilen vergi listesi, adaletsizliği ve eşitsizliği ortaya koymaktaydı. Bu listeye göre aynı mahallede bulunan Yunan ve Türk marketinin ödediği vergi kıyaslandığında muazzam bir eşitsizlik ortaya çıkmaktaydı. Yunan marketi $1.500 \mathrm{TL}$ vergiye tabi tutulurken, komşu Türk market

\footnotetext{
${ }^{4}$ British National Archives belgelerinin tamamı Rıfat N. Bali’nin eserinden alındığı için künyesi bundan sonra tekrarlanmayacak, sadece Document No verilecektir. İngiliz Ankara Büyükelçiliğinden İngiliz Dışişleri Bakanlığı'na, Document No. 2, FO 371/33389/ R 8798/1574/44- 20 Aralık 1942, Rifat N. Bali, The Wealth Tax (Varlık Vergisi) Affair Documents from the British National Archives, (İstanbul, Libra Kitapçılık 1942), s. 56.
} 
650 TL vergiye tabi tutuldu. ${ }^{5}$ Gayrimüslim cemaat, komşusu olan Müslüman Türklerden iki kattan daha fazla vergi ödüyordu. Verginin acımasız ve anlamsız uygulama yöntemi sosyal travmalara ve azınlık cemaatlerin tarifsiz acılar yaşamasına sebep oldu. İngilizler ve Amerikalılar 2. Dünya Savaşı'nın ilk yıllarında "insanlar korku ve açlıktan kurtarılacak" diyerek Atlantik Bildirisini yayınladılar (Atlantic Charter). Bu bildirideki taahhüttün Türkiye'deki azınlıkların korkularına ve açlıklarına çare olabilmesi için başta İngiliz Büyükelçiliği olmak üzere birçok sivil örgüt İngiliz Hükümeti'nin Türk yetkililerle görüşmesini ve verginin en azında hafifletilmesini talep ettiler. Türkiye'deki İngiliz Büyükelçiliği her ne kadar gayrimüslim azınlıkla ilk başlarda ilgilense de ülkedeki İngiliz tebaası birincil önceliği taşımaktaydı.

Varlık Vergisi, İngilizleri ve şirketlerini ilk başlarda direk hedef almadı. İngiliz Ankara Büyükelçiliği’nin kendi Dışişleri Bakanlığına gönderdiği telgrafta birkaç İngiliz şirketinin adil değerlendirildiği ve muamele görmesine rağmen, çoğu firma ve şahısların gelirlerinin çok üzerinde vergilendirildiğini yazmaktaydı. Bu yasa, Türkiye'deki bütün İngiliz vatandaşlarını geniş çapta etkilediğinde Büyükelçiliğin Türk hükümetine karşı kullanması gereken diplomatik ve ticari araçların ne olması gerektiği hakkında bir bilgisi yoktu. Bu anlamda İngiliz Hükümeti'nin Türkiye'ye baskı mı uygulayacağı ya da ülkemizdeki İngiliz vatandaşlarına ekonomik yardımda mı bulanacağı Büyükelçiliğin merak ettiği konular arasındaydı. İngiliz Hükümeti o dönemlerde Türk Hükümetine ciddi yaptırımlar uygulamaktan kaçınıyordu. Bir İngiliz-Türk anlaşmazlığı en çok Almanların işine yarayacağından İngiliz Hükümeti böyle bir kavgadan uzak duruyordu. İngiliz Büyükelçiliği merkezi hükümetin Türkiye'yle ilişkilerin bozulmamasına dikkat edilmesi hususuna riayet ediyordu. Öte yandan, Türkiye'deki İngiliz vatandaşlarına ve ticari çıkarlarına ciddi bir darbe vurulmaktaydı. İngiliz Ankara Büyükelçiliği'nin başlıca tereddüttü, İngiltere'nin Varlık Vergisi adaletsizliğine karş1 herhangi bir tavırda bulunmaması durumunda Türkiye'nin veya başka devletlerin onlara saygı duyup duymayacağ1 konusuydu. Büyükelçilik raporunda, bu duruma diplomatik bir çözüm sundu. Büyükelçiye göre İngiltere adil muamele için sıkı bir şekilde bask1 yaparsa ve aynı zamanda Türkiye'nin bu vergiyi alması gerektiği görüşünü kabul ederse, Türkler mevcut vergi çıkmazından çekilmenin bir yolunu bulacaklardı (Document No. 4).

Varlık Vergisi'yle ilgili İngilizlerin genel anlamda üç temel görüşü vardı. Birincisi, Maliye Bakanlığı'nın politikası nedeniyle dolaşımdaki toplam Türk Lirasının yapılacak ödemeleri karşılamak için yeterli olmayacağından vergi sistemi işleyemez duruma düşecek ve geri çekilecekti ya da verginin kasıtlı olarak Türkiye'deki tüm yabancı çıkarları yok etme politikasının bir sonucu olduğu anlaşılacaktı. İkinci nokta, İngiltere bu dönemde Türklerle anlaşmazlık riskini göze almamalıydı. Üçüncü nokta, Türk ekonomik durumunun böyle ağır bir vergiyi uygulamayı zorunlu kıldığından, İngiltere bunu Türkiye'nin bir iç meselesi olarak görmeli ve müdahale etmemeliydi. Sonuç olarak, İngiltere Türkiye'nin sermaye vergisi uygulamasına itiraz etmemeye karar verdi. Bununla birlikte, Varlık Vergisi'nin İngiliz vatandaşlarına dayatılma biçimini en güçlü şekilde protesto etme politikası izlendi (Document No. 5). İngiltere, Türkiye'yle ilişkilerini bozmamak adına adaletsiz bir şekilde vergiye tabi tutulan gayrimüslim azınlıkları kaderine terk ederken, kendi vatandaşının hakkını koruma kararı aldı.

Varlık Vergisi yasasının uygulanma şekli, yasanın başka bir amaca hizmet etmek için yapıldığına işaret etmekteydi. Yasa adeta azınlık işletme ve sektörlerini Müslüman Türk vatandaşına devrini sağlamaktaydı. Bu azınlıklar son yıllarda Türk sermayesinin büyük bir kısmını elinde bulunduran Yahudi, Ermeni ve Yunan'lardi. Vergi Kanunu altında bunlardan vergi tahsil etmek elbette Türk hükümetinin meşru bir hakkıydı. Fakat bunların çoğunun İstanbul yaşamasından buraya gönderilen vergi değerlendirme komisyonu sanki azınlıklar için "özel talimatlar" almıştı. İngiliz

\footnotetext{
${ }^{5} \mathrm{Bu}$ liste Müslüman ve gayrimüslim olan birçok işyerini karşılaştırmaktadır. Yukarıda sadece bir örneğini verdiğimiz belgenin detayı için bkz., İngiliz Ankara Büyükelçiliğinden İngiliz Dışişleri Bakanlığı'na, Document No. 3, FO 371/37399/ R 270/7/44- 25 Aral1k 1942, British National Archives.
} 
Büyükelçiliği bu durumu raporunda, "komisyonun çok ileri gittiğini ve düzgün bir şekilde vergilendirilebilir olanları aşırı miktarda vergilendirmekle kalmayıp, Türk ırkından olsaydı tamamen vergiden muaf tutulacak olan diğer birçok kişiyi de değerlendirmeye çalıştı̆̆ını" yazmaktaydı. Sonuç olarak, işletme sahibi ve orta sınıf azınlıkların ödemesi için belirlenen oranlar, onların yıkımla ve esaretle karşı karşıya kalmasına neden oldu. II. Dünya Savaşı'na özgürlük ve baskıya karşı giren İngiltere, kendi müttefik ülkesindeki baskıya çıkarları için göz yumdu. İngiliz Ankara Büyükelçiliği, Varlık Vergisi Kanunu'na "resmi müdahale kesinlikle akılsızca olacağını" ve hatta bunun "hiçbir şekilde halkın bilmemesi gerektiğini” yazarak saklamayı önerdi (Document No. 28).

Varlık Vergisine en büyük tepkilerden bir tanesi İstanbul'daki İngiliz Ticaret Odası'ndan geldi. Ticaret Odası Başkanı W.G.M. Edwards yaptığı konuşmada verginin İngiliz şirketleri ve vatandaşları üzerindeki etkisinin çok ağır olacağını ifade ederek verginin ilan edilmesinde sonra ticarette yaşanılan aksaklıkları sıraladı. Bazı ithalatçılar vergi yasasından dolayı siparişlerini iptal etmek istedi. Tüccarlar vergi mükelleflerin kaderini görmeden yeni siparişler vermek istemiyordu. Yurtdışındaki firmalar ise göndermek üzere hazırladıkları siparişleri Ticaret Odası bilgisi dahilinde durdurdular. Ticari hayatı direk etkileyen bu ve buna benzer eylemler Türkiye'de yoğun ticaret yapan İngiltere gibi ülkelerin ticari faaliyetlerini direk etkiliyordu. Edwards'ın konuşması ticari faaliyetlerle sınırlı kalmadı. Ona göre vergilendirmede, Türkiye Cumhuriyeti'nin azınlıkları bertaraf etme ve belki de yok etmek için kasıtlı uyguladığı bir politikaydı. İngiliz Ticaret Odası Başkanı vergi kanununa dair düşüncelerini, "Yunan mülkleri yüz yirmi yıl önce Yunanlılar katledilerek alındı, Ermenilere de elli yıl önce aynı şekilde muamele edildi. Bugün aynı imha ve müsadere politikasını görüyoruz, ancak bu sefer daha hassas bir şekilde planlanmış” (Document No. 10). Edwards'ın siyasete dair bu mesnetsiz iddiaları onun önyargıll, Türk düşmanı ve ırkçı olduğunu açıkça ortaya koymaktadır. Ancak ticaretle ilgili düşüncelerin de isabetli tespitler mevcuttu. Nitekim Varlık Vergisi uygulanmaya konduktan sonra yabancılar Türkiye'deki ticari faaliyetlerinin gelecekleri hakkında temkinli yaklaşmaya başladılar.

Servet vergisi İstanbul'da o kadar yüksek oldu ki, yabancılara veya azınlıklara ait birçok işyeri kapanmak zorunda kaldı. Bu durumu gören Ankara'daki İngiliz Ticaret Müşavirliği bütün İngiliz firmalarına ve vatandaşlarına çıkarlarını korumak için sevkiyatları, açık denizde halihazırda Türkiye'ye gelmek üzere olan kargoları ve Türk gümrüklerinden geçmeyen mallarını hemen durdurmalarını tavsiye etti. Gerekçe olarak Türk hükümetinin, "vergilendirme kapsamında alıcı borçlarını karşılamak için el koyma ve satma hakkını" gösterdi (Document No. 14). İngiliz vatandaş ve şirketlerinin böyle uyarılmasının sebebi vergi komisyonunun yabancıları da eşit olmayan yüksek miktarlarda vergiye tabi tutmasıydı. Verginin başladığı ilk günlerde böyle şikayetler gelmiyorken, Türkiye'deki İngiliz yetkilileri verginin uygulandığı ikinci ayda yüksek vergilendirmelerden sık sık şikâyet edip, kendi hükümetlerinden vatandaşlarını koruyacak bir çözüm bulmasını istediler. 
Tablo 1: Türk ve İngiliz Firmaları Arasındaki Vergi Adaletsizliği (Bennett Raporu)

\begin{tabular}{|c|c|c|c|c|c|}
\hline İngiliz Şirketi & Kâr & Varlık Vergisi & Türk Şirketi & Kâr & $\begin{array}{l}\text { Varlık } \\
\text { Vergisi }\end{array}$ \\
\hline $\begin{array}{l}\text { Türk Umum } \\
\text { Ticaret Ltd. }\end{array}$ & TL 90,000 & TL 108,000 & $\begin{array}{l}\text { Ömer Maliki ve } \\
\text { Oğulları } \\
\text { Kolektif Şti }\end{array}$ & TL $3,000,000$ & TL 70,000 \\
\hline $\begin{array}{l}\text { Şark } \quad \text { Yağ } \\
\text { Fabrikası ( } \% 55 \\
\text { İngiliz) }\end{array}$ & & TL 300,000 & $\begin{array}{l}\text { Bakırköy Yağ } \\
\text { Fabrikası }\end{array}$ & & TL 38,000 \\
\hline $\begin{array}{l}\text { J. Eskenazi \& } \\
\text { Sons }\end{array}$ & TL 70,000 & TL 120,000 & $\begin{array}{l}\text { Hüssameddin } \\
\text { Eren }\end{array}$ & TL 500,000 & TL 30,000 \\
\hline $\begin{array}{l}\text { S. Sourasky\& } \\
\text { Fils }\end{array}$ & TL 229,379 & TL 750,000 & Mustafa Yücat & $\begin{array}{l}\text { TL } 300,000 \\
\text { (Tahmini) }\end{array}$ & TL 20,000 \\
\hline A. Mercieca & & TL 12,000 & Halil & & TL 500 \\
\hline \multirow[t]{2}{*}{$\begin{array}{lr}\text { Tabah } & \text { ve } \\
\text { Şürekası } & (2 / 3 \\
\text { İngiliz) } & \\
\end{array}$} & & TL 180,000 & M. Rasim & & TL 35,000 \\
\hline & & & $\begin{array}{ll}\text { İsmet } & \text { ve } \\
\text { Kardeşler } & \\
\end{array}$ & & TL 30,000 \\
\hline
\end{tabular}

Varlık Vergisi İngiliz vatandaşlarına yüksek uygulanınca, İngiliz yetkililer hemen harekete geçip, iki devlet arasında imzalanan ticari antlaşmaların hükümlerini hatırlattılar. İngiltere ve Türkiye arasında 1 Mart 1930'da imzalanan Ticaret ve Seyr-ü Sefain Antlaşması'nın (the Anglo-Turkish Treaty of Commerce and Navigation) 9. ve 13. maddeleri, İngiliz vatandaşlarının ve şirketlerinin Türk vatandaş ve şirketleriyle eşit vergilendirmeye tabi tutulmuştu (Memorandum, 3 Ocak 1943). $\mathrm{Bu}$ çerçevede, İngiliz hükümeti servet vergisinde eșit muameleyi talep etmekteydi. Ancak Varlık Vergisi Kanunu azınlıkların, yabancıların ve özellikle İngilizlerin ticari faaliyetlerini hedef almıyordu. Vergilendirmedeki eşitsizlik ve adaletsizlik yasayla belirlenmeyip, uygulamada ortaya çıktığı için Ticaret ve Seyr-ü Sefain Antlaşması'nın maddelerine aykırı bir durum söz konusu değildi. Uygulamadaki bu farklılığın kanıtlanabilmesi için İngiliz ve Türk şirketlerin karşılaştırılması ve araştırılması gerekmekteydi. Böyle bir tetkik uzun zaman alacağından, birkaç İngiliz şirketinin borçlarının azaltılması dışında, iki ülke arasındaki vergi adaletsizliği tartışması vergi borçlarının tamamen silindiği 17 Eylül 1943 tarihine kadar devam etti. Fakat İngiliz Dışişleri Bakanlığı Ankara'daki Büyükelçiliğine talimat1, "İngiltere-Türkiye ilişkilerini bozacak hiçbir şeye izin verilmemelidir” oldu (İngiliz Dışişleri, Rapor, 5 Mart 1943).

İngiliz Hükümeti, Varlık Vergisinin iki ülke arasındaki ilişkiyi bozmasına izin vermediği için Türk hükümeti üzerinde uygulayabileceği baskı oldukça sınırlıydı. Ankara Büyükelçisi Sir H. Knatchbull-Hugessen'ın İngiliz tüccar ve vatandaşlarının vergisinin kendi hükümetleri tarafindan karşılanması için yaptığı öneride İngiliz hükümeti tarafından reddedildi. İngiliz Hükümetinin finansal itirazları dışında, Türkiye'deki şirket ve vatandaşlarının vergilerini sübvanse edilmesi bir şantaja yol açacağı inancı mevcuttu. Bu durumda İngilizlerin yapabilecekleri tek şey Türk hükümetine verginin adaletsiz ve ayrımcı olduğunu bildirmek ve zaman kazanmaktı (İngiliz Dışişleri, Rapor, 16 Mart 1943). Bu ekonomik buhrandan en çok şehirde yaşayan vatandaşlar etkilenmekteydi. Kırsal bölgelerde yaşayan halk kendi ekmeğini yaparak ve hayvansal ürünlerini üreterek hayatta kalmaya çalışırken, şehirde yaşayanlar çoğu zaman bu ürünlere ya ulaşamıyor ya da fahiş fiyatlarla almak zorunda kalıyordu.

Türkiye'deki İngiliz temsilcileri de aslında ülkede ki ekonomik darboğazın ve kötü gidişatın hükümeti Varlık Vergisi Kanunu'nu çıkarmaya mecbur bıraktığının farkındaydılar. Nitekim 
Büyükelçi Sir H. Knatchbull-Hugessen, Türkiye'deki mevcut ekonomik durum hakkında bilgi vermek için İngiliz Dışişleri Bakanı Anthony Eden'e gönderdiği raporunda, "Enflasyon tüm hızıyla devam ediyor, yolsuzluk yaygın ve temel ürünlerin fiyatları da yükselmeye devam ediyor.... Un kıtlı̆̆ 1 yaşanacağına dair toplumda yaygın bir korku var.... Fiyatlardaki yükselişin temel sebebi vurgunculuk, stokçuluk ve tekelciliktir” (Knatchbull-Hugessen, 10 Mayıs 1943).

İngiliz hükümeti Türkiye’yle arasının bozulmaması için Varlık Vergisi’ne genel anlamda herhangi bir tepki göstermedi. Verginin ilk uygulandığı günlerde ülkemizdeki azınlıkların haklarının korunması için İngiliz Büyükelçiliği ve Ticaret Odası çeşitli girişimlerde bulunduysa da Türkiye'yle herhangi bir gerilim yaşamak istemeyen İngiliz Dışişleri Bakanlığı durumun saklı tutulmasını ve Türkiye'nin iç işlerine müdahale edilmemesini Türkiye'deki İngiliz yetkililerine bildirdi. İngiliz Büyükelçiliği, vergisini ödemeyen azınlıkların çalışma kamplarına gönderilmesi, oradaki çalışma ve yaşama şartları hakkında detaylı bir bilgiye sahipti. H. Knatchbull-Hugessen raporunda, "Erzurum'a sürgün edilenler 50'şer kişi olarak küçük bir odada yaşıyor... Romano adında bir Yahudi kısa bir hastalıktan sonra Aşkale'de hasır üzerinde yatarken öldü" gibi bilgiler veriyordu (KnatchbullHugessen , 10 Mayıs 1943). İngiliz yetkililer bu gibi detaylara sahip olmasına rağmen azınlık konusunu ve şikayetlerini dile getirmekten geri durdu.

Ancak daha sonraki süreçte İngiliz vatandaşları ve tüccarları Türk vatandaş ve tüccarlarından daha yüksek vergilendirmelere tabi tutulunca, sadece İngiliz mükelleflerin durumunun tekrar gözden geçirilmesi ve borçlarının azaltılması için Büyükelçilik nezdinde çeşitli girişimlerde bulunuldu. İngilizlerin bu konudaki endişesi Türklerin, İngiliz şirket ve şahısların Türk Anayasasına tabi olduğunu ve Türkiye'nin iç meselesiyle ilgili olan bu teklifi değerlendirmeyi reddedeceği üzerineydi (Clutton, Rapor, 23 Haziran 1943). Fakat İngilizlerin endişesinin aksine, Türk Hükümeti bazı İngiliz şirket ve şahıslarına ait vergileri yeniden değerlendirmeye aldı. Vergi komisyonu değerlendirmeyi üç madde altında topladı. Birinci grup vergisi iptal edilen İngiliz şirket ve şahıslarında oluşuyordu. İkinci grup ise vergisi değişmeyen, başlangıçta belirlenen miktar olarak kalan İngiliz şirket ve şahıslarında oluşuyordu. Üçüncü grupta komisyonun değerlendirmesi sonucu vergi miktarı azaltılacak olan şirket ve şahıslardan oluşuyordu (Document No. 62). İngilizler verginin yeniden değerlendirilmesini ve kendi vatandaşlarının hakkını korumak için Knatchbull-Hugessen'ının Türkleri rahatsız etmeden girişimlerde bulunmasını talep ederek sadece zaman kazanmak istiyordu. Savaşın seyrini o dönemlerde tahmin etmek zor olduğundan İngilizler kendi elleriyle Türkiye'yi Almanlara itmek istemiyordu. ABD'nin de varlık vergisine dair politikası İngiltere'nin bu politikasına benzerlik gösteriyordu.

\section{ABD ve Varlık Vergisi}

Varlık Vergisi Kanunu uygulamaya girdikten sonra Türkiye'deki azınlıkların yardım talep ettiği diğer bir devlet $\mathrm{ABD}$ oldu. $\mathrm{ABD}$ Dışişleri Bakanlığı bu verginin azınlıklara yönelik olup olmadığını araştırılmasını istemesi üzerine ABD'nin Büyükelçisi Laurence Steinhardt Dışişleri Bakanı'na bir rapor gönderdi. Raporda, Varlık Vergisinin Müslüman olmayan Türk azınlıklara ve yabancılara yönelik olduğunu belirtti. Bu iddiasını somutlaştırmak için Amerikan şirketlerinde çalışan Müslüm ve gayrimüslim vatandaşların vergilendirmesini örnek verdi. Bu şirketlerden bir tanesi de Socony-Vacuum (Amerikan Petrol Şirketi) 'du. Rapora göre Socony-Vacuum'da 1942'de çalışan gayrimüslim Türklerin maaşının \%70'i vergiye tabi tutulurken, şirketin Amerikan ve Müslüman çalışanlarının maaşları vergi için değerlendirmeye bile tabi tutulmamıştı (Steinhardt, 19 Aralık 1942). Türkiye'nin bu tür vergi uygulaması yabancı devletlerin Türkiye'ye kaygıyla yaklaşmasına neden oldu. Bu anlamda, ABD Stratejik Hizmet, Araştırma ve Analiz Şube Müdürlüğü'nün Dışişleri Bakanlığına gönderdiği bir raporunda, "Türk Hükümetinin Osmanlı Devleti'nin keyfi yöntemlerine geri dönmesinden çekindiklerini” yazmaktaydı (Office of Strategic Service, 3 Mayıs 1944). 
Varlık Vergisini ödeyemeyenlerin Aşkale çalışma kampına gönderilmesi yabancı devlet diplomatları tarafından şaşkınlıkla izlendi. Büyükelçi Steinhardt, vergi kanunun uygulanışıyla gayrimüslimlerin suçlular gibi muamele gördüklerini belirtti (Steinhardt, 18 Ocak 1943). Anadolu'daki çeşitli yerel yetkililer Aralık 1943'te değerlendirme listelerini yayınladılar. Türkiye'deki ABD diplomatları vergi dağılımındaki adaletsizliği rakamlarla ifade etmek için bu listeleri ABD Dışişleri Bakanlığı'na gönderdiler. Bu listeler, Gayrimüslimlerin Müslümanlardan daha ağır vergilendirildiğini açıkça ortaya koyuyordu. Yahudi ve Hristiyan işletmeleri için belirlenen vergiler Müslüman işletmeleri için belirlenenden o kadar fazlaydı ki yapılan ayrımcıllğın gizlenmesi pek mümkün değildi (Wright, Rapor, 2 Şubat 1943).

ABD Konsolosluğu yapılan bu ayrımcıllğı fiziki olarak göstermek için Türkiye'de yüksek ve haksız vergiye tabi tutulan Gayrimüslimlerden örnekleri ABD Dışişleri Bakanlığına gönderdi. Mesela, aynı işi daha büyük sermayeyle yapan Müslüman Türkler vergiden muaf tutulmuşken, daha az servete sahip olan Müslüman olmayan Balladur isimli şahıs vergiye tabi tutulmuştur (ABD Büyükelçiliği, 20 Ocak 1943). Bu tür olaylar bir ayrımcılık vakası teşkil ettiğgi gibi Gayrimüslimlerin İngiliz ve Amerikan yetkililerden yardım istemesine de neden olmuştur. Ancak İngiliz ve ABD bürokratları kendi Dışişlerine gönderdikleri raporlarda durumu olduğundan daha farkl1, abartılı bir şekilde göstermişlerdir. Örneğin ABD’ye gönderilen belgelerde Varlık Vergisini anlatmak için sık rastladığımız ifadeler arasında "Hitler'in Yahudilere yaptıklarından daha kötüsü (worse than anything Hitler has done to the Jews) ve "çirkin ayrımcılık (Flagrant discrimination)" gibi gerçeği yansıtmayan benzetmeler ve tanımlamalar vardı (Office of Censorship, Rapor, 22 Nisan, 1943). ABD raporlarında rastladığımız bu ifadeler ABD Hükümeti'nin Türkiye'ye baskı yaparak Varlık Vergisini kaldırması için bilinçli olarak abartılmıștır. Cünkü çalıșma kampına gönderilme tehdidiyle karșı karșıya kalan Yahudi ve Hristiyan Türkler, yardım için sürekli ABD yetkililerine başvuruyorlardı.

Türkiye'ye karşı böyle çirkin ifadelerin kullanılmasının nedeni 1942'de ABD Büyükelçisi olarak Türkiye'ye atanan Laurence Steinhardt'ın da bir Yahudi olmasiydı. Yahudiler Türkiye'deki en zengin gayrimüslim cemaati olduğu için doğal olarak bu vergiden en çok onlar etkilendiler. Steinhardt'ın Türkiye'ye atanması, Varlık Vergisi'nin uygulanmasına denk geldi. Büyükelçi Steinhardt, Amerika Birleşik Devletleri'nin Türkiye'ye atanan tek Amerikan Yahudi'si değildi, Beyaz Saray Türkiye'ye çok sayıda Yahudi atadı. Alman propaganda ajansları, ABD'nin savaştan sonra Orta Doğu'yu Yahudilere devretmek istediğini iddia ettiği için ABD Dışişleri Bakanlığı bu konuda oldukça tedirgin oldu. Alman ajansları, iddialarını Türkiye'deki üç ana ABD ajansı etrafında topladılar: Dışişleri, Ödünç Verme ve Kiralama Bürosu ve Savaş Bilgi Bürosu. Üç Yahudi, Steinhardt, Cardoza (Kauffmann'ın yerine geldi) ve Lehrman Türkiye'deki bu Amerikan ajanslarını yönetti. Almanlar, diğer iki Yahudi yönetimindeki on iki subayın bile farkında değildi: Karl Austrian ve Harold Guinzburg. Ayrıca, ABD Hazine Bakanlığı Koumoudjinsky adlı bir Bulgar Yahudi Bankacısını da Türkiye'ye göndermek istiyordu (Steinhardt, 26 Haziran 1943). Belki de bütün bu Yahudilerin Amerika Birleşik Devletleri tarafindan Türkiye'ye atanması bir tesadüf değildi; muhtemelen Balkanlardan Yahudileri kurtarmak için bir zemin oluşturuluyordu. Diğer alternatif ise Almanların dile getirdiği gibi ABD Ortadoğu'yu savaştan sonra Yahudilerin kontrolüne bırakmak istiyordu. Ancak ABD'nin buraya neden bu kadar Yahudi Amerikalıyı atadığını arşiv belgelerinde rastlayamadık. Fakat, ABD Dışişleri Bakanlığı'nın 1942'de Büyükelçi Steinhardt'a gönderdiği bir telgrafta, Varlık Vergisi'ni Türk makamlarıyla görüşmemesi gerektiğini belirtti (Steinhardt, 11 Ocak 1943).

ABD ve Büyük Britanya başlangıçta Varlık Vergisi ile ilgili yayınlanan yayınlarını sansürlediler. The London Times gazetesi, 1943 Ocak ayına kadar vergi ile ilgili bir dizi makale yayınlasa da, bu makaleler genel olarak Türk hükümetinin vergi kararına sempati ile bakıyordu. Amerikan hükümeti de Türkiye'yle ilişkilerini bozmak istemediği için C. L. Sulzberger'in 9-13 Eylül 1943 'te New York Times'ta peş peşe bastığı beş makale dizisine kadar vergi ile ilgili hiçbir makalenin çıkmasına sıcak bakmadı (Office of Strategic Service, 3 Mayıs 1944). Türkiye ile politik ilişkilerini 
olumlu tutmaya çalışan ABD yetkilileri, Amerikan basınını "Türk-Amerikan ilişkilerini veya genellikle Türkiye ile ABD arasındaki ilişkileri tehlikeye sokabilecek hiçbir şey yayınlanmaması gerektiği” konusunda uyardı (Office of Strategic Service, 3 Mayıs 1944). ABD Hükümetinin uyarılarına rağmen, Varlık Vergisi ile ilgili sürekli şikâyet alan Sulzberger, Varlık Vergisi'nin adaletsizliğini ABD kamuoyuna açıklamak için New York Times'taki köşesinde bir dizi makale yazdı. Sulzberger, Varlık Vergisinin ana hedefinin enflasyonu düşürmek ve yaklaşık bir milyonu aşan ordunun masraflarını karşılamak için fon sağlamak olduğunu yazmasına rağmen, verginin "doğrudan Hristiyan ve Yahudi azınlıkları zayıflatmaya yönelik bir çaba" olduğuna da ifade etmesi dikkat çekiyordu (Sulzberger, 9 Eylül 1943). Varlık Vergisi taraftarlarının, verginin azınlık karşıtı önyargılar içermediğini ve ülkeyi kurtarmak için acil bir önlem olduğunu defalarca söylese de, Sulzberger, "Hristiyan ve Yahudi işletmelerine uygulanan vergilerin, benzer Müslüman Türk işletmelerinden çok daha ağır" olduğunu yazılarında ifade ediyordu. Bunula birlikte, Sulzberger makalesinde "Korkulan iğrenç ayrımcılığın sadece tespit edilmediği, hatta aşırıya kaçıldığı" sonucuna vardığını yazıyordu. Ayrıca, Sulzberger "verginin gayrimüslim olmayanları işsiz bırakmak ve bu nedenle Türk ticari hayatındaki azınlık kontrolünü bir kez ve bütünüyle ortadan kaldırmak için tasarlandığını" iddia ediyordu (Sulzberger, 11 Eylül 1943). Varlık Vergisi Kanunu'na yönelik eleştirilerini sıralarken, Türkiye'yi milliyetçi, rrkçı ve hatta Avrupa devletleri gibi faşist bir ülke tasvir ediyordu. Türkiye'nin içinde bulunduğu şartları, toplumun sosyal durumunu ve ekonomik gelir dağılımı hakkında bilgi sahibi olmayan Sulzberger, 19. Yüzyıldaki oryantalistlerin Ortadoğu'yu tasvir ettiği gibi Türkiye'deki vergi uygulamasını başkasının ağzıyla ve gözüyle yazıyordu. Türkiye' deki sermayenin önemli bir kısmı Yahudilerin ve gayrimüslimlerin elinde olduğundan, onlar doğal olarak daha çok bu vergiden etkilendiler (Bali, 424-441).

Bazı ülkeler Varlık Vergisi'ni açıkça eleştirirken, ABD vergiye karşı tutumunu açıklamaktan kaçındı. Türkiye, 1942'de Varlık Vergisi'ni uygularken hem ABD'nin aktif bir müttefikiydi hem Almanya'yla bir dostluk anlaşması imzalamıştı. Almanya'nın 1942'ye kadar Kuzey Afrika'nın çoğunu işgal etmişken ve Rusların Stalingrad'daki Almanları yeneceği kesin değilken, Amerika Birleşik Devletleri ve Müttefik Güçler böyle bir ortamda Varlık Vergisi Kanunu eleştirmenin doğru olmadığını düşündüler. Zaten böyle bir zamanda, Beyaz Saray veya Müttefiklerin vergiyi eleştirerek Türk hükümetini rahatsız etmesi pek akıllıca olmazdı. Türk tarafsızlığ 1 o dönemde Müttefikler için hayati öneme sahipti. Müttefiklerin yanlış bir hamlesiyle Almanya'nın yanında savaşa girecek olan Türkiye en çok Müttefiklere zarar verecekti; Rusya'ya karşı yeni bir cephe daha açılacaktı. Aynı şekilde Müttefiklerin yanında savaşa girecek olan Türkiye, diğer Balkan devletleri gibi Almanlar tarafindan kısa bir süre içinde işgal edilip Rusya’ya karşı yine yeni bir cephe açılmış olacaktı. Tarafsız bir Türkiye Müttefiklerin savaş politikasına daha çok yarıyordu. Müttefik Devletler, Varlık Vergisi Kanunu bu yüzden uzun süre gündemlerine almamışlardı. Bununla birlikte, Yunanistan'ın diğer ülkelerin nüfusuna kıyasla Türkiye'de daha fazla vatandaşı ve ortak dindaşı bulunduğundan, Yunanistan Büyükelçiliği Varlık Vergisi'ni sert bir şekilde protesto etti. Ancak, koşullar Yunanlıların herhangi bir fiziksel eylemde bulunmalarını engelledi (Sulzberger, 12 Eylül 1943).

Türk Hükümeti, Varlık Vergisi'nin kabulü ve uygulanışı döneminde Yahudi mültecilerin Filistin'e geçişine veya Türkiye'ye girişine genel itibariyle engel olmamaya çalıştı. Başka bir ifadeyle, Varlık Vergisi uygulaması Yahudi kurtarma operasyonlarına son vermedi. Örneğin, Dobrudja bölgesine yerleşmiş 2.000 Musevi, 1940 yılının Ekim ve Kasım aylarında Türkiye'ye geldi. Yine Kasım ayında Türkiye'ye Romanya, Bulgaristan ve Yunanistan'dan göç eden 5.200'den fazla Yahudi kadın ve erkeğe Türk vatandaşlığı verildi (MacMurray, Rapor, 6 Mart 1941). Yahudi göçleri Türkiye'ye savaşın sonuna kadar devam etti. Büyükelçi Steinhardt, ABD Dışişleri Bakanlığından aldığı emir gereği Varlık Vergisi konusunu Türk hükümetiyle görüşmekten kaçınmasına rağmen, özellikle Balkanlardaki Yahudi mültecileri kurtarmak için Türk makamlarıyla yakın çalıştı. Amerikan Yahudi Ortak Dağıtım Komitesi'nden Büyükelçi Steinhardt'a gönderilen bir rapor, Varlık Vergisinin Yahudileri Türkiye'ye gelmesini engellemediğini gösteriyordu. Rapora göre 1942'de, 
"Vizeye sahip olmayan 120 Rumen Yahudi küçük bir tekneyle kaçtı ve İstanbul yakınlarında battı... Türk makamlarının muazzam çabaları sayesinde [Rumen Yahudi Mülteciler] kurtarıldılar" (Baerwald, Rapor, 20 Ekim, 1942). Türk Hükümeti insani yardım söz konusu olduğunda geri durmamış, elindeki imkanlar dahilinde Yahudi mültecilerin kurtarılması için çaba sarf etmiştir. Türk Hükümeti'nin, Büyükelçi Steinhardt'ın ve Amerikan Yahudi Ortak Dağıtım Komitesi'nin çalışmalarıyla 1944'e kadar Balkanlardan ve Avrupa'dan binlerce Yahudi mülteci kurtarıldı. Türkiye'nin bu kurtarma faaliyetlerini göz ardı ederek, sadece Varlık Vergisi üzerinden 1rkçı olarak tanımlamak ideolojik ve yanlış bir tanımlamanın ötesine geçememektedir. Nitekim, Türkiye ırkçı bir politika yürütmüş olsaydı, Balkanlardan gelip Türkiye üzerinden Filistin'e giden binlerce Yahudi'nin geçişine izin vermezdi.

\section{Sonuç}

Türkiye, cumhuriyetin kuruluşundan sonra bazı alanlarda olduğu gibi ekonomik alanda da iktisadi Türkleştirme politikası gütmüş olması oldukça olağan bir durumdur. I. Dünya Savaşı'ndan sonra kurulmuş olan ulus devletlerin birçoğu bunu ırkçılık ve düşmanca tavırlarla yapmasına rağmen, Türkiye savaş yıllarında cephelerde savaşan devletin asli unsurunu eşit bir zeminde iktisadi hayata dahil etmiştir. II. Dünya Savaşı'nın getirmiş olduğu ekonomik yükü hafifletmek ve ülke savunmasını güçlendirmek için bazı olağan üstü vergilendirme yöntemlerine başvurulmak zorunda kalındı. Bur vergi kanunları ayrımcılık ve eşitsizliği içermemesine rağmen, bazı yerel yönetimlerin bunu gayrimüslimleri ötekileştirmek ve ekonomik gücünü kırmak için kullandıkları anlaşılmaktadır. Türk azınlık cemaatleri ağır vergi yüklerinden kurtulmak için İngiltere ve ABD'den sık sık yardım istemlerine rağmen 1944'e kadar resmi düzeyde olumlu bir cevap alamamışlardır. Çünkü bu iki devletin önceliği Almanya'nın mağlup edilmesiydi. Tarafsız bir ülke olan Türkiye'nin iç meselesi olan azınlık sorunuyla ilgilenip ilişkilerini bozma riskini göze almak istemediler. Böyle bir teşebbüs Türkiye'yi Almanya' yla yakınlaştırabilirdi. İngiliz ve ABD arşiv belgelerinden anlaşılacağı üzere bu devletler Türkiye'deki temsilcilerinin bu sorunla ilgilenmesini dahi istememişlerdir.

\section{Kaynakça}

Akar, R. (2009). Aşkale Yolcuları: Varlık Vergisi ve Çalışma Kampları. Doğan Kitap.

Aktar, A. (2004). Varlık Vergisi ve 'Türkleştirme' Politikaları. İletişim Yayınları.

Ankara ABD Büyükelçiliğii. (1943). Ankara ABD Büyükelçiliği'nden at the Secretary of State'te, 20 Ocak 1943. Washington D.C.: National Archive.

Baer, M. D. (2010). The Dönme: Jewish Converts, Muslim Revolutionaries, and Secular Turks. Stanford University Press.

Baerwald, P. (20 Ekim 1942). The American Jewish Joint Distribution Committee'ye ve Laurence A. Steinhardt'a Rapor. Washington D.C.: Library of Congress.

Bali, R. N. (2010). Cumhuriyet Yıllarında Türkiye Yahudileri: Bir Türkleştirme Serüveni (19231945) (8. b.). İletişim Yayınları.

Bali, R. N. (2012). The Wealth Tax (Varlık Vergisi) Affair Documents from the British National Archives. Libra Kitapçılık .

Barutçu, F. A. (1977). Siyasi Anılar 1939-1954. Milliyet Yayınlar1.

Bennett, J. S. (1942). Inngiliz Büyükelçiliği'nden Dışişleri Bakanı Numan Menemencioğlu'na, "Further Examples of Discrimination Between Turkish and British Controlled Firms," 31 Arallk 1942, . Londra: British National Archives. 
Bozkurt, M. E. (1930, Eylül 19 ). Adliye Vekili Mahmut Esat Bozkurt'un Ödemiş Nutku. Hakimiyeti Milliye.

Büyükelçiliği, İ. (1942). İngiliz Ankara Büyükelçiliğinden İngiliz Dışişleri Bakanlığı'na, Document No. 5, FO 371/33389/R 8996/1574/44- 28 Aralık 1942. Londra: British National Archives.

Clutton, G. (1943). Document No. 52, FO 371/37404/ R 5323/7/44- 23 Haziran 1943. Londra: British National Archives.

Deringil, S. (2012). Conversion and Apostasy in the late Ottoman Empire. Cambridge University Press.

Edwards, W. (1942). Speech Delivered by Mr. Edwards (Chairman) at Meeting of British Chamber of Commerce, Istanbul, Document No: 10, FO 371/37400/ R 642/744- 30 Aralık 1942. Londra: British National Archives.

İki Yahudi çocuğu hava kurumu için toplanan rozet paralarını çaldılar. (1942, Ağustos 31 ). Cumhuriyet.

İngiliz Büyükelçiliği. (1942). İngiliz Ankara Büyükelçiliğinden İngiliz Dışişleri Bakanlığı'na, Document No. 2, FO 371/33389/R 8798/1574/44- 20 Arallk 1942. Londra: British National Archive.

İngiliz Büyükelçiliği. (1942). İngiliz Ankara Büyükelçiliğinden İngiliz Dışişleri Bakanlı̆̆ı'na, Document No. 28, FO 371/33389/R 9020/1574/44- 28 Aralık 1942. Londra: British National Archives.

İngiliz Büyükelçiliği. (1942). İngiliz Ankara Büyükelçiliğinden İngiliz Dışişleri Bakanlı̆̆ı'na, Document No. 3, FO 371/37399/ R 270/7/44- 25 Aralık 1942 . Londra: British National Archives.

İngiliz Büyükelçiliği. (1942). Ingiliz Ankara Büyükelçiliğinden İngiliz Dışişleri Bakanlı̆̆ı'na, Document No.4, FO 371/33389/R 9004/44- 27 Arallk 1942. Londra: British National Archives.

İngiliz Dışişleri Bakanlığı. (1943). "From Foreign Office to Angora," Departmental No.2, FO 371/37402/ R 2074/7/44- 5 Mart 1943. Londra: British National Archives.

İngiliz Dışişleri Bakanlığı. (1943). War Cabinet Distribution to Turkey: From Foreign Office to Angora, FO 371/37402/ R 2458/7/44- 16 Mart 1943. Londra: British National Archives.

İngiliz Ticaret Müşavirliği. (1942). From the Commercial Councellor, Ankara, Document No: 14, FO 371/33389/R 9094/1574/44- 31 Aralık 1942. Londra: British National Archives.

İstifçi iki Yahudi yakalandı. (1942, Eylül 9 ). Tasvir-i Efkâr.

Knatchbull-Hugessen, S. H. (1943). Sir H. Knatchbull-Hugessen'den Mr. Eden'a, Document No. 44, FO 371/37403/R 4490/7/44- 10 Mayls 1943. Londra: British National Archives.

Laurence A. Steinhardt. (1943). Laurence A. Steinhardt Papers, 26 Haziran 1943,. Washington D.C. : Library of Congress.

Lewis, B. (1961). The Emergence of Modern Turkey. Oxford University Press .

MacMurray, J. V. (6 Mart 1941). Current Developments in Turkey during the Months of November and December, 1940. Washington D.C. : National Archive.

Mahmut Esat Bozkurt. (1938, Ağustos 22 ). Ulus Gazetesi.

No 108. (1942, Kasım ). Ayın Tarihi. 
No. 105. (1942, Ağustos ). Ayın Tarihi.

Office of Censorship. (1943). Middle East, Gizli Dosya, Report no. 5354, 22 Nisan 1943. Washington D.C. : National Archive.

Office of Strategic Service. (1944). Research and Analysis Branch to the Department of State, May 3, 1944, no.1903, . Washington D.C. : National Archive.

Office of Strategic Service. (1944). Office of Strategic Service'ten Research and Analysis Branch to the Department of State'te, no.1903, 3 Mayls 1944. Washington D.C. : National Archive.

Ökte, F. (1987). The Tragedy of the Turkish Capital Tax. Croom Helm.

Steinhardt, L. (1942). Büyükelçisi Laurence Steinhardt'tan ABD Dışişleri Bakanı'na Rapor, 19 Arallk, 1942. Washington D.C.: National Archive.

Steinhardt, L. (1942). Laurence Steinhardt'tan the Secretary of State'te, 19 Aralık 1942. Washington D.C. : National Archive.

Steinhardt, L. (1943). Laurence Steinhardt'tan ABD Dışişleri Bakanı'na Rapor, 18 Ocak 1943. Washington D.C: National Archive.

Sulzberger, C. L. (1943, Eylül 12 ). AnkaraTax Raises Diplomatic Issues. New York Times.

Sulzberger, C. L. (1943, Eylül 9). Turkey is uneasy over Capital Levy. New York Times.

Sulzberger, C. L. (1943, Eylül 11). Turkish Tax Kills Foreign Bussiness. New York Times.

(1941). The Atlantic Charter, 14 Ağustos 1941, . Washington D.C.: National Archives.

The Department of State. (1943). Department of State'ten Laurence A. Steinhardt'a, 11 Ocak 1943. Washington D.C.: National Archive.

Tural, M. A. (1987). Atatürk Devrinde İktisadi yapılaşma ve Celal Bayar (1920-1938). Kültür ve Turizm Bakanlığı Yayınları.

Üstel, F. (1997). Imparatorluktan Ulus Devlete Türk Milliyetçiliği Türk Ocakları 1912-1931. İletişim Yayınlar1.

Varlık Vergisi Bakayasının Terkinine Dair Kanun. (1944, Mart 17 ). T.C. Resmi Gazete.

Varlık Vergisi Hakkında Kanun. (1942, Aralık 11 ). T.C. Resmi Gazete.

Varlık Vergisi Kanunu Bütün Şartları ile Tatbik Edilecektir. (1943, Ocak 21 ). Cumhuriyet Gazetesi.

Varlık Vergisi Kanununun çalışma Mecburiyetine Dair Hükümleri ihtiva eden 12 ve 13 üncü Maddelerinin Tatbik Sureti Hakkında Talimatname. (1943, Ocak 12). T.C. Resmi Gazete.

Wright, W. L. (2 Şubat 1943). Memorandum on The Varlik Vergisi or Capital Tax. Washington D.C.: National Archive. 